\title{
O Espírito e a Esperança: um estudo sobre a relação entre Espírito Santo e a esperança cristã na Pneumatologia de Jürgen Moltmann a partir da Teologia da Esperança
}

\author{
Orientador: Cesar Augusto Kuzma \\ Mestrando: Lucas Soares dos Santos \\ Área de Concentração: Teologia Sistemático-Pastoral \\ Linha de Pesquisa: Fé e Cultura
}

A missão do Espírito Santo possui aspectos que com o avanço da teologia ganharam maior atenção pelos teólogos e as diversas tradições cristãs. Jürgen Moltmann, entre um grande número de teólogos, desenvolve uma reflexão original e complexa sobre o Espírito Santo, começando em sua famosa "Teologia da Esperança" e tendo como ápice a produção do livro "O Espírito da vida", obra dedicada exclusivamente à reflexão sobre o Espírito Santo. Ele produzirá uma Pneumatologia que será orientada pela sua concepção de Escatologia cristã e pelos textos bíblicos do Apóstolo Paulo. Essa pesquisa tem como objetivo principal fazer uma abordagem sobre como Jürgen Moltmann apresenta a relação entre o Espírito Santo e a Esperança Cristã, tendo como ponto de partida os acenos teológicos que ele desenvolveu na "Teologia da Esperança", seu primeiro livro. Nossa abordagem se dividirá em três diferentes etapas. Em um primeiro momento, iremos nos dedicar a apresentar os principais textos produzidos por teólogos ao refletirem sobre o Espirito Santo. Em seguida, este trabalho vai fazer uma apresentação dos principais aspectos da Pneumatologia moltmanianna através de suas principais obras. $\mathrm{O}$ último passo, então, é discorrer sobre como Jürgen Moltmann compreende a relação entre Espírito Santo e a Esperança Cristã. Após a pesquisa, concluímos que nosso autor produz uma Pneumatologia que deve ser lida a partir da 
Escatologia que ele fomenta em sua Teologia da Esperança. O Espírito Santo é compreendido como o poder vivificante de Deus que faz com que homens e mulheres possam experimentar as promessas do futuro, parcialmente, ainda no presente. Ele garante que elas serão cumpridas e impulsiona a Igreja, que vive na esperança de uma realização plena do que foi prometido, a caminhar dentro da história sinalizando o Reino vindouro por meio de suas ações.

Palavras-chave: Espírito Santo. A esperança cristã. Escatologia. 